A. D. Krivolap, PhD of Philosophy in Culture Studies,

Belarusian State University of Culture and Arts,

17, Rabkorovskaya Street, Minsk, 220007, Belarus

\title{
POSSIBILITIES AND LIMITATIONS OF CULTURAL STUDIES FOR RETHINKING THE SOVIET HERITAGE
}

The article is devoted to the answer to the question how that became possible when culturology was translated into English as Culture studies? There is no danger of losing something in translation, there is a huge conceptual mistake. The work is devoted to the problem of specific cultural forms of adaptation and using terms of culturology. There is a deep and large challenge for social and cultural discourse reflex and explain the difference between culturology and culture studies. The purpose of this text is to describe this academic discourse of culturology and to understand the conditions for the possibility of its existence and underline some differences from culture studies. Culturology was proposed in the western academic tradition but broadly adopted and welcomed in post-Soviet space.

Culturology can be understood as a broad social and cultural phenomenon that brings deep consequences to society in transition. The postSoviet reality can be studied in the frame of postcolonial discourse and culturology will have a chance for new-born again to solve new social challenges. Against the background of serious values about the Soviet past, the critical attitude to Soviet aesthetics does not seem unexpected. Rethinking the Soviet past should begin not with political or economic aspects, but with aesthetic and cultural issues. The discourse of culturology contributes to the creation of a certain vision of the social and physical realities. We will try to consider this process by the example of the approach of culturology to the problem of identity. It is interesting that different visions, what cultural identity is, exist simultaneously. On the one hand, cultural identity is considered as a normative requirement to meet certain socio-cultural requirements, historical ideals that have been tested for centuries and strive for their revival. But, on the other hand, cultural identity is interpreted as an endless process of social formation and the search for answers to new questions and social challenges. The first approach is more typical for culturology, and the second-for culture studies.

Key words: culturology, decommunization, rethinking, culture studies.

А. Д. Криволап, канд. культурологии

Белорусский государственный университет культуры и искусств,

ул. Рабкоровская, 17, г. Минск, 220007, Беларусь

\section{ВОЗМОЖНОСТИ И ОГРАНИЧЕНИЯ КУЛЬТУРОЛОГИИ ДЛЯ ПЕРЕОСМЫСЛЕНИЯ СОВЕТСКОГО НАСЛЕДИЯ}

Посвящено ответам на два вопроса: что не так с переводом культурологии на английский язык как культурных исследований? И каким образом дискурс культурологии может быть полезен в процессе десоветизации? Рассмотрена проблема конкретных культурных форм адаптации и использования терминологии культурологии. Цель этого текста - показать концептуальные отличия культурологии от культурных исследований, а также описать возможности дискурса культурологии для работы по переосмыслению советского наследия. Культурология была предложена западной академической традицией, но широкое распространение получила на постсоветском пространстве. Постсоветская ситуация может изучаться в рамках постколониального дискурса. Дискурс культурологии способствует созданию определенного видения социальной реальности. C одной стороны, культурная идентичность рассматривается как нормативное требование для удовлетворения определенных социокультурных потребностей, реализации исторических идеалов, проверенных веками. Но, с другой стороны, культурная идентичность трактуется как бесконечный процесс социального формирования и поиска ответов на новые вопросы и социальные вызовы. Первый подход более характерен для культурологии, а второй - для культурных исследований.

Ключевые слова: культурология, декоммунизация, переосмысление, культурные исследования.

удк 130.31:130.2(045)

А. Ю. Морозов, д-р фрілос. наук, доц. Київський національний торговельно-економічний університет, вул. Кіото, 19, м. Київ, 02156, Україна a.morozov@knute.edu.ua

М. М. Рогожа, д-р фрілос. наук, проф. Київський національний університет імені Тараса Шевченка, вул. Володимирська, 60, м. Київ, 01033, Україна mrogozha@ukr.net

\section{ТРАНСПЕРСОНАЛЬНИЙ ДОСВІД ЯК ВІДПОВІДЬ НА ВИКЛИКИ НІГІЛІЗМУ: ЄВРОПЕЙСЬКИЙ КОНТЕКСТ}

Приділено увагу питанню духовності як екзистенційної налаштованості людини на священну таємницю буття. Будучи трансцендентною, царина священного в акті епіфанії проявляється у різноманітних символічних формах особистісного досвіду. Стверджується, що духовністю раr excellence виступає трансперсональний досвід, який сполучає особистість з таємницею священного як "незбагненного" не інтелектуально, а шляхом буттєвої співпричетності. У цьому інтуїтивному акті духовного натхнення людині відкривається невимовна істина речей по той бік "фактів" i "текстів". Трансперсональний досвід є конститутивним у процесі становлення людини, їі олюднення. У ньому відбувається "трансценденція" індивідуального, що передбачає постійний рух самовдосконалення та самоподолання, "розширення свідомості". Це можна назвати духовною ініціацією шляхом поступового морального преображення особистості через символічну смерть і воскресіння, метою якого є реалізація буттєвої повноти ії існування, досягнення стану щастя-блаженства. Наводяться історичні форми духовної ініціації, такі як античні містерії і християнське таїнство Євхаристії. Особливу увагу зосереджено на аналізі платонівського розуміння натхненняшаленства. Зазначено, що в надрах сучасної секулярної культури, що є наслідком нігілістичної установки на "розчаклування світу" та морального релятивізму, неминуче зароджується ностальгія за священним.

Ключові слова: трансперсональний досвід, нігілізм, моральний релятивізм, істина буття, факти і речі, мовчання, натхнення, духовність, символ, містерії, ностальгія.

Постановка проблеми. Прагнення індивіда віднайти смисл власного існування, досягти духовноціннісної і буттєвої повноти (з-бути-ся і від-бути-ся) $\epsilon$ споконвічним та універсальним. Ніщо не паралізує людську волю так сильно, як тривожне відчуття абсурдності, беззмістовності власного існування, знецінення світу (див. детальніше аналіз тривоги абсурду в класи- чних роботах П. Тілліха "Мужність бути", Р. Мея "Про сенс тривоги" та В. Франкла "Людина в пошуках сенсу" [22; 10; 29]). У свою чергу, "воля до смислу" (В. Франкл) як вроджена людська інтенція та екзистенційна потреба у своїх граничних проявах тісно пов'язана із переживанням особою вищих безумовних цінностей добра, краси, щастя-блаженства. Останнє супроводжується 
відчуттям безмежної радості, любові-емпатії до всього сущого як блага, усвідомленням безкінечності власної особистості, ілюзорності смерті тощо. Досвід щастяблаженства $€$ своєрідним показником того, наскільки воля до смислу була успішно втіленою. I навпаки: депресії, фррустрації, апатії, суїцидальні стани, нігілістичне відкидання культурних традицій, постмодерністська байдужість або іронічне ставлення до великих наративів культури, їі класичних цінностей та ідеалів свідчать про поразку чи слабкість цієї волі.

Кореляція понять "смисл життя" - "цінності/чесноти" - "щастя" в межах традиційних культур (античності, християнства, Далекого Сходу) була самоочевидною. щоправда, через суттєву різницю в метафізичних картинах світу можливі різні інтерпретації. Чи $є$ щастяблаженство ("евдемонія") як вершина реалізації усіх людських можливостей і ціль розумного існування результатом однієї лише праведності і життя згідно чеснотам? І чи достатньо нам однієї лише етики (або навіть етикету) для реалізації найвищої мети життя? Чи можливий інший варіант, коли щастя-блаженство не залежить виключно від зусиль людини і потребує трансцендентного ("не-світового") джерела, того, що, наприклад, у християнстві називається духовним "молитовним досвідом", що дається благодаттю Святого Духа? Іншими словами, питання стоїть таким чином: чи $є$ повнота духовного розвитку людини станом природним (реалізацією внутрішньо закладених потенцій природи людини, що не потребує виходу за межі "Я", тобто чистою само-реалізацією) або над-природним (тобто таким, де вимагається специфічний трансперсональний досвід, в якому долається "само-", "самість")?

Мета статті - проаналізувати сутнісні характеристики трансперсонального досвіду, показати його різні історичні форми в європейській культурі.

Аналіз досліджень і публікацій. Оскільки трансперсональний досвід $є$ міждисциплінарною проблемою, то він перебуває у фокусі уваги фрілософрів, релігієзнавців, психологів, істориків культури, богословів тощо. Теоретичні основи його аналізу заклали К. Уілбер ("Око духа"), А. Маслоу ("Психологія буття"), М. Еліаде ("Історія віри та релігійних ідей"), Є. Торчинов ("Релігії світу. Досвід трансцендентного. Психотехніка і трансперсональні стани"). Окремі аспекти трансперсонального досвіду в домодерній культурі (на матеріалі античності і візантійської традиції) вивчали Р. Генон, В. Малявін, В. Отто, О. Шмеман, С. Сахаров, П. Мінін та інші. Фундаментальні світоглядні і методологічні орієнтири для вивчення трансперсонального досвіду були прокладені в класичних працях М. Гайдеґґера, Л. Вітгенштейна, Ч. Тейлора.

Виклад основного матеріалу. Вади "іманентної парадигми". Якщо ми обмежуємося природою, обто працюємо, умовно кажучи, в "іманентній парадигмі", то ця епістемологічна стратегія рано чи пізно (через низку історико-фрілософських опосередкувань) виведе нас до матеріалістичного розуміння природи взагалі і природи свідомості зокрема, до неминучого висновку, що щастя $\epsilon$ епіфеноменом складних біохімічних процесів, що відбуваються в мозку. Відповідно, вирішення сенсожиттєвої проблематики у межах цієї стратегії переноситься у вульгарну матеріалістичну (позитивістську) площину перетину психіатрії, нейрофрізіології, дієтології, фрармацевтики і т. д., тобто відповідної техніки "нормалізації" біохімії мозку. Сьогоднішній рівень науки дозволяє розробляти ліки практично від усіх симптомів "екзистенційного вакууму", про які сповіщали В. Франкл, Е. Фромм, П. Тілліх, Р. Мей, К. Юнг та інші дослідники гуманістичного напряму в психології і теології: депресії, тривожності, апатії, агресії тощо. Прийняв відповідну пігулку - і став "щасливим": відчув збудження, ейфорію, бадьорість, безстрашність, безмежну любов до всіх (потрібне підкреслити). Закінчилася дія ліків-наркотиків (до речі, англійське слово "drug" має саме такий подвійний переклад) - і буттєва повнота щастя-блаженства згортається назад: до нудьги й абсурду повсякденності, царини безособового ("Das Man"). Ясно, що подібна терапія носить симптоматичний характер, але не лікує причини захворювання, адже тут розривається відкритий стародавніми мудрецями, а сьогодні майже забутий причинно-наслідковий зв'язок між щастям і чеснотами, які необхідні для його досягнення.

Техніка досягнення щастя в межах "іманентної парадигми" може носити й більш складний, соціальноінженерний характер, коли за допомогою маніпулятивних технологій в масову свідомість впроваджують стереотип, за яким щастя дорівнює певному наборові "знаків щастя" (Ж. Бодріяр). Так формується тип "нормальної" людини-конформіста, що грає за правилами гри суспільства споживання. Щастя зводиться до речей і послуг, які демонструють певний статус особи в суспільстві: одяг, машина, будинок, гаджети і т. д. Відповідно, нещасна людина - лузер (невдаха), який з тих чи інших причин позбавлений "знаків щастя". Ще гірше положення у того, хто не бачить в отриманні "знаків щастя" сенсу - така людина для ідеології консюмеризму $є$ ненормальною, девіантною. Це - злочинець, божевільний, маргінал, внутрішній емігрант. Е. Фромм у роботі "Мати чи бути?" доволі ретельно описав хибність, марність і вульгарність (пошлість) такої матеріалістичної установки на отримання, володіння і накопичення. Тому ми не будемо спеціально на цьому зупинятися.

Фактичність $\boldsymbol{i}$ контрфактичність. Говорячи про проблему смислу і цінностей людського існування в межах "іманентної парадигми", доцільно послатися на знамениту тезу Л. Вітгенштейна про те, що "світ це сукупність не речей, а фрактів" (афоризм №1 [1]). Ця теза одразу ж стикається із проблематичністю пояснення символічного світу культури, в якому живе людина, тобто ціннісного виміру. Адже емпірично вивести з фактів їхню норму, якість, а відтак смисл і цінність (оцінку) неможливо. Цінності - контрфактичні. Існування людини - це емпіричний "факт", але в чому смисл і цінність цього фракту? "Факт" і "цінність факту" (і зрештою - "смисл фракту") належать до різних порядків буття. Це можна порівняти з різницею між двовимірним і тривимірним простором.

Цінності не є і не можуть бути предметом строгої науки. Це принципово не-наукова сфера компетентності. Л. Вітгенштейн в "Логіко-фрілософському трактаті" пише: "Сенс світу має перебувати поза ним. У світі все таке, як воно є, і все діється, як діється, у ньому немає жодної вартості, а якби була, не мала би вартості. Якщо $€$ якась вартість, що має вартість, то вона має перебувати поза всім, що діється і так-існує. Бо все, що діється і так-існує - випадкове" (афоризм 6.41) [1]. І далі ще один характерний пасаж: "Якщо стануть відомими всі факти світу, головні питання життя (етичні, світоглядні питання. - Прим. наші) не будуть навіть порушені". Якщо моральні цінності контрфактичні, то про них наука нічого не може сказати. Про цінності можна лише мовчати, вказуючи на їхнє місце в логічній структурі світу та пізнавальному процесі: "Етика трансцендентальна. Етика і естетика - єдині" (афоризм 6.421) [1, с. 83-84].

Здавалося б, така постановка питання має суто негативні наслідки з етичної точки зору. Якщо сенс мають лише емпіричні ("атомарні") факти, тоді твердження "політика Гітлера в 1930-ті роки щодо євреїв полягала в "остаточному вирішенні" єврейського питання" 
має смисл, адже спирається на факти. Тоді як твердження "політика Гітлера в 1930-ті роки щодо євреїв $\epsilon$ моральним злом і злочином проти людяності" вже не $€$ фактом, а отже, не має логічного смислу, адже науково не доведеними / не проясненими залишаються ключові метафізичні поняття: "зло", "добро", "людяність", "моральне" тощо. Отже, позитивістська картина світу, унеможливлюючи строгі з наукової точки зору етичні судження, так чи інакше приводить нас до ситуації морального нігілізму. Водночас позитивізм показує, що "головні питання життя" залишаються метафізичними питаннями і доступні в особливому стані мовчання. "Про що не можна говорити, про те слід мовчати". Ясно, що мовчання, про яке йдеться у Вітгенштейна, - це не логічне заперечення мовлення, не просто відсутність звуку/шуму чи штучна пауза в розмові, коли співрозмовникам немає про що говорити. Ні! Мовчання - специфічний досвід вдивляння-споглядання, де інтенсивно переживаються невимовні (невербальні) речі. Як і що саме переживається у досвіді мовчання, в "Логікофрілософському трактаті" не тематизується, а лише натякається. Можна припустити, що в останньому короткому афоризмі Трактату в імпліцитному вигляді міститься відсилка і до платонізму, і до візантійського ісіхазму, і до буддистських молитовних станів (див. детальніше про Вітгенштейна як містика [2; 19]). 3 методологічної точки зору важливим $є$ те, що показуються межі наукової компетенції і водночас окреслюється екзистенційна (ціннісно-смислова) сорера, де царюють ненаукові фрорми пізнання (релігія, містика, поезія). Логічний позитивізм заперечує метафрізику як науку, але не заперечує її предметне поле. Саме 3 цієї методологічної конструкції можна намітити подальший шлях до тих трансперсональних форм пізнання, які долають замкнену шкарлупу іманентності і націлюють людину на трансцендентне, контрфактичне.

тотальність тексту. Подальший розвиток "іманентної парадигми" веде нас від логічного позитивізму до остаточної деконструкції метафізики. Факт - це певна подія, яка може бути описана в тексті - письмовому чи усному. 3 фактів складається певна оповідь, "наратив", який "відповідає" на інший наратив, вступає із ним в діалог (підтверджує, заперечує, сумнівається, вірить, іронізує, запитує знову і т. д). Отже, сказати, що "світ це сукупність фактів", по суті, те ж саме, що сказати, що "світ - це сукупність текстів". Останні становлять певний культурно-історичний контекст, який, у свою чергу, веде діалог з іншими культурно-історичними контекстами, і так далі до безкінечності. Це гігантські архіпелаги текстів $€$ автономними системами, у яких, як запевняють нас постструктуралісти, "означальне" відривається від "означуваного" (об'єктивності речей), а "автор помирає" (Р. Барт). Відповідно, заперечується авторська монопольна позиція на єдину правильну інтерпретацію тексту, усувається будь-яка смислова ієрархія (істина-хиба, краще-гірше, піднесене-вульгарне). В цій тотальності тексту ("немає нічого поза текстом")конкретні цінності і норми оголошуються конвенціональними, дискурсивними, історично і культурно обумовленими, існуючими і породженими в конкретному часо-просторі культури.

Утім, стверджувати, що цінності є лише контекстуальними, дискурсивними, означає знову "удар" по етиці, що завершується релятивізмом і нігілізмом. Тільки вдумаємося! В одному тексті Гітлер $є$ Прометеємвизволителем арійської раси, в другому - прокляттям Європи і катом, в третьому - персонажем коміксу, в четвертому - ліричним героєм пісні, який викликає жіночі симпатії, і так далі. В одному дискурсі Голокост це сувора і трагічна реальність, в іншому цей же самий
Голокост - фрарс і містифікація, в третьому - тема анекдоту із серії "чорного гумору". У цьому "поліфонічному" (М. Бахтін) розмаїтті позицій, точок зору, "голосів" тоне авторська метапозиція: оскільки всі ці тексти $є$ рівноцінними, то не існує істини текстів. Жоден не може претендувати на істинність, універсальність, незаангажованість. Якщо цінності - це тексти, що народжуються в інших текстах, відповідно для опису символічного світу підходить постмодерністська модель "різоми" (Ж. Дельоз) - грібниці, в якій відсутні класичні метафізичні опозиції центру і периферії, духовних "висот" і "низин" (за М. Бердяєвим), добра і зла. 3 психіатричної точки зору така різома свідчить про шизофренічний діагноз, патологію мислення, де розщеплюється "Я" як трансцендентальний центр, що уможливлює єдність особистості. Натомість замість цього центру починають конкурувати між собою різні "персони" (в юнгіанському сенсі цього слова).

Отже, позитивістська і постструктуралістська картини світу унеможливлюють існування універсальних, об'єктивних та необхідних моральних цінностей. Звідси логічно випливає один практично значущий результат. Якщо добро, зло, природа людини і т. д. суть метафізичні, контрфактичні поняття або в кращому разі контекстуально обумовлені відносні і мінливі "дискурсивні домовленості", то ми не можемо оперувати жодними моральними і правовими категоріями, що претендують на універсальність, як, наприклад, "злочин проти людяності", "злочин без строку давності", "гуманізм", "природні права", "сумління", "гідність" і т. д. Якщо "тексти" історії людства можуть бути переписані і щоразу по-іншому інтерпретовані, відповідно немає жодного сенсу в існуванні музеїв пам'яті Голокосту чи жертв Хіросіми та Нагасакі, фондів захисту прав і свобод громадян тощо. Коли заперечуються універсальні цінності, розпадається світ, в якому ми живемо, "розсипається" як абсолютно ненаукова і бездоказова вся західна політична риторика про демократію як універсальну форму правління, про необхідність розповсюдження демократії в недемократичних країнах і т. д. Утім, логічна суперечливість подібного ціннісного шизофренічного "розщеплення" очевидна. Адже твердження "не існує універсальних ціннісних констант" повинно підпадати під свою ж власну вимогу, тобто не може бути універсальним. Коли проголошується, що "все відносно та історично", то в першу чергу відносною та історичною $€$ сама ця проголошена теза.

"Назад до речей". Щоб уникнути подібних крайнощів нігілізму і знайти можливість оперувати універсальними й об'єктивними цінностями, потрібно повернутися до того, що знаходиться поза фрактичністю і текстом (а значить, і поза теоріями, концепціями, інтелектуальними надбудовами і моделями), - "назад до речей" (Е. Гуссерль). Світ - це не лише фракти, події, предмети мислення і тексти, а передусім "речі". Ясно, що у випадку смислів і цінностей ідеться про "речі" в ідеальному значенні цього слова. В платонізмі речі - це "ейдоси", у феноменології - "феномени свідомості" (ноеми), у фрілософії Дж. Сантаяни - "царство сутностей", в системі А. Уайтхеда - "ідеальні об'єкти", у Ж. Дерріда - гіпотетичне "трансцендентальне означуване" і т. д. Для Гайдеґґера речі - це особливий рід буття, їх ми можемо оцінювати через "четверицю буття", що утворена парами протилежностей: небо-земля, боги-смертні. [див. 30]. Через речі промовляє "істина буття", а через категорію "буття" можна вийти до наступної категорії "благо", адже все суще в силу своєї причетності до істини буття $€$ благом. Метафрізичний трикутник буття-істинаблаго уможливлює всі подальші фрілософські і теологі- 
чні спроби побудови ціннісної ієрархії. Цінності і смисли - це речі, що речуть, "промовляють до нас з висоти" (Д. Ф. Гільдебранд), закликають до свого втілення. Водночас речі, що не є фактами і містяться поза текстом, потребують особливого бачення-розуміння, тобто особливого інтуїтивного трансперсонального досвіду прозріння в їхню сутність. Без цього досвіду ми приречені перебувати у "ціннісній сліпоті" (М. Шелер, Д. Ф. Гільдебранд), небажанні відповідати на їхній виклик.

Що ж до тези про історичну обумовленість цінностей і анти-універсалістські тенденції, то на це можна відповісти, що сама можливість розрізнення порядків буття сущого і належного, фактів і цінностей - універсальна і метаісторична. Тобто можливість розрізнення не $є$ культурно обумовленою, а виступає апріорною умовою можливості будь-якої культури взагалі. Здатність наділяти фракти смислом і цінністю - це своєрідна "трансцендентальна граматика культури" (термін наш), без якої факти не мали б ніякого сенсу. Факти "нанизуються" (себто пояснюються, інтерпретуються, оцінюються) лише за допомогою цієї "трансцендентальної граматики". А ця граматика, в свою чергу, не була би дійсною, якби вона не спиралася на об'єктивність речей, а відтак і об'єктивність їх цінностей. (Тут можна послатися на М. Шелера і Н. Гартмана, які використовували поняття "матеріального апріорі" в етиці та обстоювали принцип об'єктивної ієрархії цінностей).

Як відомо, сфера трансцендентального - це прерогатива метафрізики. Відтак проблематика смислу і цінності буття як такого, людської "волі до смислу" (телос якої, як вже було сказано вище, $€$ верховні цінності) виводить нас, так чи інакше, за межі "природи" і "фактів", на шлях до релігії, яка є квінтесенцією метафрізичних (духовних) пошуків людства.

Духовність як зв'язок між індивідуальним та надіндивідуальним (трансперсональним). Так само як для "іманентної парадигми" щастя, задоволення, спокій (tranquility) $€$ епіфеноменами матеріальних (біологічних, фрізичних, хімічних) процесів в організмі, так i для релігійної (умовно "над-природної") парадигми вони також трактуються як похідні, побічні продукти - але вже не матеріальних процесів, а певної духовної роботи і духовного досвіду, від яких вони отримують свою значущість. Важливою $є$ ремарка Г. Гегеля про те, що "таємниця щастя полягає у здатності виходити з кола свого Я" [3, с. 304]. Можна взяти ії̈ за точку відліку подальших міркувань. Це означає, що замкнена в своєму егоїзмі особа відчуває свою збитковість і несамодостатність. Тільки розмикаючи коло індивідуального світу в акті трансценденції (переростання індивідуальних меж), долаючи самоцентрованість і монологічність, стаючи частиною цілого, людина досягає буттєвої повноти і душевного миру. "Ексцентричність" (термін Е. Левінаса) людської екзистенції, покладання смислового центру не в собі, а назовні, показує її залежність від Іншого, марність всіх зусиль побудувати монадоподібну автономну "самість" (selfness). Водночас Інший, його "обличчялик", як правильно зауважує Е. Левінас, у своєму внутрішньому світі безкінечно відмінний від Я, тобто $€$ абсолютно Іншим. Така абсолютна "іншість" ближнього поруч $з$ нами неминуче відсилає нас до монотеїстичної концепції Бога-Особистості, абсолютно Іншого від створеного ним світу. Таким чином, ми поступово підходимо до питання про смисловий центр ваги для особи, яка, долаючи "коло свого Я" (Гегель), прагне смислу і щастя. Дороговказом для нас буде саме слово існування (existentia), яке споріднене зі словом ecstasis. Екстатичність існування свідчить про те, що воно, по-перше, черпає життєві сили не з самого себе, а із зовнішнього джерела, а по-друге, що постійний процес самоподолання ("виходу із себе"), очевидно, має абсолютний смисловий горизонт, на фоні якого і в напрямку якого він відбувається. Іншими словами, якщо екзистенція це трансценденція, то існує й те, що кардинал Карл Ранер називав "Куди-і-Звідки трансценденції", священна і невимовна таємниця буття.

Стародавні мудреці стверджували, що індивідуальна свідомість ("я мислю") не є відправною точкою відліку в світі і що онтологічною мірою всіх речей виступає царина абсолюту (Першо-розуму). Згадаймо Геракліта Темного, який попереджав своїх учнів: "слухай не мене, а Логос..." [28, с. 51]. Особистість народжується у співпричетності індивідуального до надіндивідуального. Тільки у цій націленості до "вершин буття" (М. Бердяєв) вона ціннісно зростає і розширяється. I навпаки: екзистенційна відмова від служіння надіндивідуальним смислам і цілям, байдужість до "високих" надзавдань, відсутність "смаку до вічності" (саме так Шлейермахер визначав сутність релігійної свідомості) завершуються стагнацією "особистісності" (personhood) як принципу. Чим більше сучасна секулярна людина зациклена на "своєму", суто індивідуальному, партикулярному, тим менш вона щаслива і тим частіше вона відчуває відчуження, самотність, екзистенційний вакуум, які вона найчастіше компенсує: нестримним гедонізмом, наркотиками, немотивованою агресією, моральним і правовим нігілізмом, уходом в сектантство, віртуальну реальність і т. д. Проф. Чарльз Тейлор в роботі "Секулярна доба" називає індивідуалізм "моральною хворобою модерності" [21]. Ми характеризуємо цю хворобу як втрату духовності, або "деперсоналізацію" (не в психіатричному, а саме в моральному сенсі цього слова, хоча ці два аспекти між собою, безумовно, пов'язані).

Що ж таке духовність? Сьогодні часто-густо вживають поняття дух, духовність у переносному, алегоричному значеннях, дедалі більше розмиваючи їхній первинний смисл. Під "духовним" тут і далі ми розуміємо прояв буття як священної таємниці божественного ("Куди-і-Звідки трансценденції") в повсякденному світі та символічну форму вираження цієї таємниці в особистісному досвіді. Іншими словами, духовність - це налаштованість людини на священне; останнє, в силу цієї налаштованості, відкриває себе конкретній особі у формі епіфанії ("богоявлення"). Без цього явленняепіфранії трансцендентна царина священного завжди залишалася б абсолютно непроникною таємницею, непізнаваною "річчю-в-собі". Заперечення епіфанії (можливості досвіду зустрічі з божественним) веде до крайнощів кантівського агностицизму і подальшої антиметафізичної нігілістичної лінії фрілософування. Завдяки духу (гр. "нус") особистість $є$ онтологічно розімкненою структурою, якій приодчиняється священна таємниця буття. Якщо використовувати традиційну термінологію, духовний досвід $€$ вікном, крізь яке в темряву матеріального світу потрапляє світло "божественних енергій" (Г. Палама), що наповнює життя людини вищим смислом. У більш сучасних термінах можна назвати це "піковим переживанням" (А. Маслоу), переживаннямціллю, в яких особа досягає абсолютного горизонту трансценденції, "остаточної" відповіді на фундаментальні екзистенційні питання. У цьому піковому переживанні людині відкривається бачення сутності речей такими, якими вони є у своєму бутті, а також справжній смисл власного існування.

Трансперсональний досвід як духовність par excellence. Трансперсональний досвід - не просто один з проявів духовного, поряд із моральним та естетичним. На наш погляд, це духовний досвід par 
excellence. Він підносить індивідуальне існування людини, сполучаючи ії через низку сходинок з таємницею священного і "незбагненного" (С. Л. Франк). Як відмічає дослідник П. Мінін, такий досвід, на відміну від абстрактного пізнання, якісно змінює життя людини [11]. Трансперсональний досвід, або досвід буття (в цьому випадку будемо розглядати їх як синоніми), є конститутивним у процесі становлення людини, її олюднення. Без нього людина втрачає свій привілейований онтологічний статус, розлюднюється, перетворюється на річ серед інших речей, людський матеріал. Водночас у цьому досвіді відбувається "трансценденція" індивідуального, що передбачає постійний духовний рух вдосконалення та самоподолання. Цей "рух вгору" можна назвати також духовною ініціацією, тобто символічною смертю і воскресінням, шляхом поступового морального преображення особистості. Наприклад, візантійська аскетична традиція називає це "метаноєю", тобто кардинальною переміною розуму, самого способу буття, смертю старої (вітхої) людини і народженням нової людини, що досягла богоподібності (святості). Аналогічне духовне преображення (описане в термінах "просвітлення", "звільнення" тощо) можна знайти також в далекосхідних практиках.

Зауважимо також, що трансценденція як осердя трансперсонального досвіду ніколи не є в чистому вигляді "самотрансценденцією", бо неможлива без посутнісної відкритості Іншому через довіру, емпатію тощо. Можна порівняти це із фізичною неможливістю здійснити відомий трюк барона Мюнхгаузена: витягнути самого себе за волосся з болота. Про яке "болото" би не йшлося - фрізичне, екзистенційне, культурно-історичне - опори виключно на самість, на само-стояння, на внутрішні резерви недостатньо. "Істина буття", персоналізована в особі Бога авраамічних релігій або богів (як, наприклад, боги гайдеґґерівської "четвериці буття") чи деперсоналізована (даосизм, буддизм),є джерелом, рушійною силою і кінцевою метою трансценденції.

Релігійне натхнення. Частина I. Античність. Одним із конститутивних елементів релігійного досвіду $€$ "натхнення". Саме слово "надихати" етимологічно споріднене із "дихати", а дихання, у свою чергу, пов'язане із духом ("pneuma"). Отже, ідеться не про повсякденне (побутове) розуміння, а більш глибинне значення цього слова. "Духовне натхнення" потребує відповідної налаштованості, підготовки, входження в певний психоемоційний стан, який сьогоднішні психологи би назвали "зміненим станом свідомості", "трансперсональним досвідом" (К. Уілбер). Ризикнемо стверджувати, що у житті видатних постатей таке духовне натхнення часто було джерелом знання і творчості. Ось, наприклад, як свідчив про Геракліта Діоген Лаерцій: "3 дитинства він був диваком: в молодості говорив, що не знає нічого, а коли подорослішав - що знає все. Він не був нічиїм учнем, але, за його словами, випитав самого себе і дізнався про все від самого себе" [7, с. 47]. Знання, яке отримав Геракліт, було миттєвим, немов блискавка божественного Вогню-Логосу. Згадаймо також Парменіда, який у пролозі фрілософської поеми "Про природу" сам зізнається, що богиня відкрила йому таємниці істинного буття. Тому багато філософських положень Парменіда (наприклад, тотожність буття і мислення) $є$, очевидно, інтуїціями-прозріннями, що були відкриті у трансперсональному досвіді.

Дуже ретельно тема натхнення, що асоціюється 3 божественним безумством-несамовитістю, розроблена у Платона. Ця тема показує, наскільки штучним і надуманим є сучасний світський поділ між фрілософією та релігією. Адже для Платона божественне натхнення виступає релігійним фрундаментом фрілософського дос- віду, без якого ми не можемо полишити звичайне повсякденне життя ("печеру") і доторкнутися до основ сущого, над-розумного цілого. Несамовите натхнення джерело творчого мислення, що здатне до уяви, мистецтва думати образами, а не концептами. Шаленство, як і смерть, - це два напрями одного і того ж самого фундаментального питання про буття, тому що ми як мислячі істоти в смерті знаходимо межу свого тілесного (тваринного) існування, а в шаленстві - межу свого розумного існування. Водночас і смерть, і шаленство тісно пов'язані із сутністю філософування. Філософрія покликана готувати людину до смерті, коли вона нарешті зможе остаточно вийти з печери невігластва та побачити справжній світ вічних ідей.

Що ж до безумства-натхнення, то без нього людина ніколи не почне мислити по-фрілософськи, тобто зазирати в сутнісну глибину речей, а не ковзати по їх поверхні: "Філософру притаманно відчувати здивування. Воно і $€$ началом фрілософрії" (Теэтет, 155 d) [16]. Подив, здивування виражають відповідний настрій людини, що стала свідком чогось непересічного, дивовижного, незвичайного, такого, що виходить за межі звичайного сприйняття і здорового глузду. Подив означає входження у сферу несамоочевидного, яке вражає нас і приголомшує. Дуже сильно здивуватися означає прийти в стан несамовитості, нестями (рос. исступления), тобто буквально "вийти за межі розуму".

Дивовижне, як ми вже зазначали вище, для Платона певним чином співвідноситься 3 божественним, надлюдським. В екстатичному подиві-натхненні людині відкривається божественне. Це відкриття є даром "богів". "Метафізичний стрибок" до нового бачення означає миттєву одержимість та безумну несамовитість, "манію", тобто "божественну зміну звичайного стану" (Федр 265 a). Манія як дар Божий є джерелом найвищих благ та істинного знання. "Нестяма прекрасніша від розсудливості, бо та походить від Бога, а ця властива людям" (Федр, 244 d) [16]. Розсудливість - людська чеснота, а шаленство-натхнення - Богом дана можливість бачити (=розуміти) інтелігібельний світ ідей.

Платон (вустами Сократа) розрізнює два види несамовитості: "а нестями бувають двох видів: один $€$ наслідком людських захворювань, а другий має місце тоді, коли людина з волі богів відхиляється від звичайного стану" (Федр, 265 а) [16]. В свою чергу, в божественній манії Сократ виокремлює чотири види: пророчу, що походить від Аполлона, містеріальну - що навіюється Діонісом, поетичну, що надсилається Музами, й еротичну, що дарується Афродітою та Еротом. Пророкування $€$ особливим божественним даром натхнення. Манія не означає нестачу розуму, слабоумство чи скудоумство, втрату адекватності, відсутність самосвідомості тощо. Це особливий захват розуму, вихід за межі здорового глузду. На думку М. Мусіна, аполлонівське пророче шаленство $€$ "катарсичним" (очищуючим) мисленням. Можна також назвати його морально спрямованим і аскетичним мисленням, адже у молитві Сократа наприкінці діалогу "Федр" лунають такі рядки: "Дорогий Пан та інші тутешні боги! Наділіть мене внутрішньою красою, а зовнішнє у мене нехай буде у згоді із внутрішнім" (Федр, 279 b) [16]. Поєднання фрізичного і духовного світла є основним атрибутом бога Аполлона. "У своїй чистоті Аполлон подібний до сонячного світла, що несе світле прозріння, а несамовите натхнення, що дарує Аполлон, є духовною ясністю радісного пізнання, що відкриває істину" [12, с. 73]. Аполлон - бог порядку і міри, фрормоутворюючий дух. Аполлон втілює стремління людини до прекрасної форми, що поєднує різні частини в одне-єдине органічне ціле. 
"Якщо епітетом Аполлона є чистий, променистий, сяючий, то епітетами Діоніса є той, що звільнює, дозволяє, розв'язує" [12, с. 74]. Це божество втілює ідею становлення, руху, спонтанність і непередбачуваність. Аполлон роз'єднує, встановлює кордон і межу, норму, яку не можна переступати. Діоніс, навпаки, об'єднує, скасовує кордони і протиріччя, відміняє норми, розмиває межі індивідуального, дає можливість індивіду перестати бути самим собою. Він скасовує смисл і порядок, захоплює душу в темряву хаосу - простір, де сходяться протилежності, життя і смерть.

Аполлонічне "катарсичне" й аскетичне мислення і діонісійське відкриваюче й "емансипуюче" мислення тісно пов'язані з поетичним натхненням. "Всі добрі епічні поети складають свої прекрасні поеми не завдяки вмілості, а бувши натхненними і одержимими" (Ioн 533 e) [16]. Поет, немов бджола, збирає свою творчість у медоносних джерелах в садах і дібровах Муз. Поет здатний творити лише в стані нестями, коли він нібито втрачає відчуття здорового глузду. Поетична манія передбачає пристрасну молитву, благання богів, щоб вони подарували поетичне натхнення.

Найкращий тип шаленства - любовний, або еротичний. Ерот виражає досвід цілісності, поєднуючи духовну і матеріальну природу в людині, божественне і тваринне. В еротичному шаленстві знаходиться "той, хто дивлячись на земну красу і згадуючи справжню, окрилюється, і окрилений, прагне злетіти". Він не піклується про те, що внизу, а дивиться вгору, прагне злетіти, немов птах (Федр 249 c-d) [16]. Еротична манія захоплює людину, збирає всі ії інтелектуальні, вольові і чуттєво-емоційні сили в єдине ціле, піднімає до трансцендентного джерела усього сущого, дарує найвище щастя-блаженство.

Тепер кілька слів скажемо про символізм релігійного досвіду. Реальність, що відкривається в духовному досвіді, є вищою за мову. Вона осягається не дискурсивно, а інтуїтивно-споглядально. Згадаймо, як в діалозі Платона "Кратіл" Сократ стверджує, що мова не досягає істини сущого і що ми повинні пізнавати суще із нього самого, не застосовуючи імен (слів). Мислення, яке інтуїтивно осягає ідеї, може виходити з-під влади імен. Таким чином, з точки зору цієї логіки, початок і кінець руху думки - це тиша, інтуїтивне споглядання, буттєва співпричетність до речей, а дискурс і аргументація - всього лише пауза в тиші.

Напрошується паралель між давньогрецькими і давньо-китайськими доктринами, зокрема з ученням про Дао. Лао Цзи писав про "безіменне Дао" як єдиний сокровенний принцип, таємницю, виток і джерело всього. Його не можна назвати, але на нього можна вказати, натякнути. Відомий китаєзнавець Володимир Малявін відзначає: "Для даоського патріарха думка і буття одне, але Лао Цзи - майстер "темних речей", тому у нього не мова нав'язує свій порядок буттю, а саме буття проступає крізь мову... Це мова, що повертається до чистого повідомлення-сполучення. В ньому зіяє буття" [9, с. 40]. Тут ідеться про сполученість, причетність до реальності того, що знаходиться по той бік речей і водночас пронизує ці речі, немов кров'яні судини. Речі поєднані, сполучені між собою і знаходяться у співпраці без всяких слів. Однак першоєдність речей не схоплюється категоріально. " Хоч би про що говорив Лао Цзи, він має на увазі "інше" і навіть "вічно інше"' [9, с. 41]. Якщо смисл лежить по той бік мови та речей, то нам нічого не залишається, як повторити вслід за Лао Цзи: "знаючий не говорить, той, хто говорить, не знає" [9, c. 41]. Можна порівняти цей давньокитайський афоризм з аналогічним висловлюванням Людвіга Вітгенштейна:
"Про що не можна говорити, про те слід мовчати" [1]. Те, про що слід мовчати, зовсім не означає, що його не існує в реальності або що воно не має смислу і цінності. Навпаки, воно $€$ абсолютно значущим, однак не може стати предметом розгляду науки з її опорою на "атомарні фракти". Більш того, самі смисли речей не $€$ "атомарними фактами", адже вони не є емпіричними об'єктами. Як писав Ж. Дельоз (і це дивним чином корелює із тим, про що говорили давньокитайські і давньогрецькі мудреці): "Смисл завжди припускається, як тільки я починаю говорити... Смисл розгорнутий одним боком до речей, а іншим до речень. Але він не зливається ані $з$ реченнями... ані 3 якістю, яке дане речення позначає. Він $€$ саме межею між реченнями і речами" [5, с.45]. Таким чином, ми не здатні "висловити смисл того, про що говориться, тобто в один і той же час висловити дещо і його смисл" [5, с. 45]. Абсолютно значуще, про що мовчать чи символічно натякають, $є$ фрактом особливого, неповсякденного досвіду.

Містерії. Говорячи про тишу, в якій передається невимовне божественної реальності і відбувається таємнича трансформація людини через смерть і воскресіння, доцільно згадати про давньогрецькі Елевсинські містерії. До наших днів залишилося вкрай мало документальних свідчень про них. Це було пов'язано із забороною під страхом смертної кари учасникам церемонії розповідати, що вони пережили. Єдине, що дійшло до нас, - поодинокі цитати з античних творів, які натякають на деякі подробиці церемоніалу. В загальних рисах зрозуміло, що в основі містерій лежало бажання людини возз'єднатися з божеством і отримати блаженне вічне життя. У гомерівському гімні на честь богині Деметри є такі рядки:
Деметра... всіх посвятила в таїнства.
Святі вони і величні. Про них ні питати
Права не має ніхто, відповісти на розпит ще гірше:
У шанобі до безсмертних великих вуста замовкають.
Той з земнородних людей, хто таїнства бачив, - щасливий.
Той, хто до них не причетний, не буде вовік після смерті
Долі подібної мати в темному царстві Аїда
(470-80 строки). [14, с. 120-122.].

Схожі слова знаходимо у поета Піндара: "Щасливий той, хто бачив це (містерії), перед тим, як спуститися під землю. Йому відомий кінець життя. Він також знає його начало" [15, с. 31], і у драматурга Софокла: "Тричі щасливі ті смертні, що бачили ці таїнства і спустяться в Аїд, тільки вони зможуть мати справжнє життя там, для решти все там - страждання" (фрагмент 719) [20]. Отже, посвяченому було обіцяно, що його душа буде насолоджуватися блаженством після смерті і що вона не стане простою "тінню без пам'яті і сили" (стан, якого так бояться усі герої Гомера). Містерії повинні були нагадувати смертним події священної історії, символічно відтворювати сюжет викрадення Аїдом, володарем царства мертвих, улюбленої доньки Деметри - красуні Персефони - та подальшого щасливого возз'єднання двох богинь. Таким чином містерії демонстрували стирання неподоланної межі між світом мертвих і світом живих, можливість символічного посередництва між світами.

Історія Персефони давала людству надію на диво воскресіння. В цьому аспекті містерії - результат спроби дарувати смертній людині фрізичне безсмертя. 3 міфрічної оповіді ми пам'ятаємо, що Деметра хотіла перетворити царського сина на бога за допомогою випалювання в печі, але за роковим збігом обставин самі люди завадили довести справу до кінця. Невдача Деметри призвела до епіфанії (богоявлення) богині людям та встановлення містерій. 3 того самого часу як зерно бо- 
жественного посаджено в людську душу, розпочинається внутрішня трансформація скотоподібної істоти, в якій панують тваринні інстинкти-пристрасті, у людину як богоподібну істоту, в якій дух домінує над плоттю. Показовою ілюстрацією цього процесу є роман Апулея "Метаморфози, або Золотий осел", в якому розповідається історія перетворення людини на віслюка внаслідок темних чар. Численні подорожі віслюка завершуються несподіваним фіналом: допомога богині Ісіди повертає йому людське обличчя. Переживши духовне відродження, головний герой стає служителем ії культу. В даному випадку релігійне навернення головного героя символізує подолання грубого тваринного начала, моральне вдосконалення через катарсис. Удари сліпої долі завершуються містеріальною нагородою-посвятою головного героя: "Потім жрець, відсторонивши всіх непосвячених, накидає на мене плащ з грубого льняного полотна i, тримаючи за руку, веде в святая святих храму. Ласкавий читачу! Можливо, ти, зацікавившись, запитаєш, про що мовилось там, що там робилося? Звичайно, я радо сказав би тобі про це, якби можна було говорити, а ти дізнався б, якби можна було тобі слухати. Але й вуха, і язик однаково поплатилися б за таку зухвалу цікавість. Зрештою я не буду довше тримати тебе в очікуванні, якщо ти охоплений побожною жадобою пізнання. Отож слухай і вір мені, що це чиста правда. Я дійшов уже межі між життям і смертю, торкнувся порога Прозерпіни і знову вернувся, пройшовши через усі стихії. Опівночі я бачив сонце в сліпучому сяйві, опинився віч-на-віч з підземними й небесними богами i зблизька бив їм земні поклони. Ось я й розповів тобі, що і як, а ти, хоч і почув, вдавай, ніби нічого не знаєш. А тепер повідомлю тільки те, що без гріха святотатства можу виявити непосвяченим слухачам" [8, с. 539]. В ініціації відбувається друге народження людини, від якого залежить посмертна участь душі, або те, що пізніше християнська теологія назве спасінням.

Обряди малих містерій супроводжувалися жертвоприношенням, постом, а також поїданням священної їжі. Вони також включали в себе мандри в темряві (що символізували мандри душі після смерті), різноманітні жахливі видовища, театралізовані вистави і несподіваний вихід на освітлений яскравим світлом луг, що символізувало звільнення душі від страждань і досягнення нею блаженства. Вальтер Отто пише, що учасникам церемонії показували колос пшениці і далі відбувалося "чудо". Колос виростав і визрівав з неймовірною швидкістю, так само як під час діонісійських містерій за декілька годин виростала виноградна лоза. В кульмінаційний момент церемонії розігрувалася вистава, де зображувалося, як Персефона возз'єднується зі своєю матір'ю. Неофіт долучався до божественної таємниці, і відбувалася радикальна зміна свідомості. "У посвяті неофіт відчував близькість до божественного світу, а також тісний зв'язок життя і смерті. Одкровення про взаємоперетинання життя і смерті мало примирити неофріта з необхідністю власної смерті" [34, с. 127].

Рене Генон вказує на глибинне метафрізичне значення містерій. За його реконструкцією, малі містерії стосувалися розвитку можливостей людської природи, приводили до досконалості, відновлення первісного "райського" (блаженного) стану, а великі містерії вели до реалізації надлюдських, необумовлених станів того, що східні традиції називають "остаточним звільненням", або вищим ототожненням. Піднімаючись по сходинках станів буття, людина повинна була стати живим дзеркалом, в якому Божество споглядає свою власну сутність, а ії серце - оселею і храмом Духа. Р. Генон також звертає увагу на спільну етимологію слів "міф" і "містерія". Слово "міф" походить від слів "закритий рот", "німий", а відтак означає "мовчання". В свою чергу, містерія, таємниця також пов'язана з ідеєю мовчання. Спорідненими є слова "містика" та "міст" (посвячений), пов'язані з ініціацією. Отже, містерія - це те, про що не можна говорити, про що заборонено розповідати стороннім людям. $€$ також схожість між словами "сакральний" і "таємний". Сакральне - те, що недоступне мирському, віддалене і відокремлене від нього. Отже, містерія стосується того, що слід приймати у мовчанні, про що не слід сперечатися. Генон підкреслює, що релігійна догматика завжди є містеріальною. В ній закладені істини, які мають надраціональну і надіндивідуальну природу і не можуть обговорюватися. Містерія невиразна, і їі треба споглядати у мовчанні, передаючи невимовне у символічній формі [4, с. 361-363].

Релігійне натхнення. Частина II. Християнство. Християнська (передусім візантійська) традиція також розуміє божественне натхнення як серцевину духовного трансперсонального досвіду і таким чином продовжує містичну лінію філософування, розпочату греками. Змінюється розуміння Бога, але незмінним залишається усвідомлення того, що в релігійному досвіді індивідуальна замкнена структура "его" розмикається і вводиться в сферу надіндивідуального, сакрального, надсущого. Відомий православний подвижник XX ст., нещодавно канонізований грецькою церквою Константинопольського патріархату, св. Софроній (Сахаров) пише: "При всьому усвідомленні моєї крайньої нікчемності, я молився десятиліттями, щоб Господь дав натхнення на слідування за Ним, куди б Він не пішов... Під натхненням я розумів присутність сили Духа Святого всередині нас. Цього роду натхнення належить іншому порядку буття, щодо того, що я приймав за художнє або фрілософське натхнення. I це останнє може бути зрозуміле як дар від Бога, але ще не дає ані єднання з Богом особистим, ані навіть інтелектуального ведення (розуміння) про Нього. Справді святе натхнення, що від Отця сходить, не нав'язується силою нікому: воно отримується, як і будь-який інший дар від Бога, напруженим подвигом в молитві. ...Всім нам необхідно зазнати повне переродження дією благодаті, відновлення в нас здатності сприйняти обоження" [17, с. 103]. Таке духовне переродження під дією натхнення подвижник, вслід за традицією святих отців, називає обоженням (теозісом). Воно полягає в подоланні смерті й отриманні вічного життя. Причому обоження є спів-дією (синергією) індивідуального Я і божественного Іншого. Тільки завдяки цим спільним зусиллям, у підкоренні своєї волі божественному Одкровенню, людина може жити праведним життям згідно з євангельськими заповідями, серед яких центральне місце посідає любов-милосердя. Євангельські заповіді називаються "заповідями блаженств", відповідно, життя по заповідях дає особі можливість відчути ("вкусити") блаженство, або "мир Христовий": "Істинне обоження полягає в тому, що розумній істоті дійсно і навіки невід'ємно передається безначальне життя самого Бога... Натхнення зверху залежить від нас: чи відкриємо ми двері серця нашого, щоб не насильно увійшов всередину нас Господь - Дух Святий, який стоїть біля дверей серця нашого і стукає. Коли душа (саме таким чином, тобто через божественне натхнення. Прим. наші) буттєво торкається цієї Вічності, тоді відпадають від нас ниці пристрасті... на нас сходить "мир Христовий", і ми отримуємо силу любити ворогів і здійснювати інші Христові заповіді" [17, с. 104].

Ще один православний подвижник XXст., ігумен Валаамського монастиря Харитон також пише, що молитовне предстояння людини перед Богом, її автентич- 
ний, а не імітаційний релігійний досвід передбачає "синергію", тобто спільну дію людської і божественної волі, поєднання довільності і мимовільності. "Чого шукають молитвою Ісусовою? - Того, щоб канув в серце благодатний вогонь і почалася безперервна молитва, чим саме і визначається благодатний стан... Молитва Ісуса, коли іскра Божа впаде в серці, роздуває її в полум'я, але сама не дає цієї іскри, а лише сприяє прийняттю її. Іскра Божа - промінь благодаті. Його нічим не спричиниш, він виходить прямо від Бога... Цей вогник ніякою майстерністю не приваблюється, а подається вільно благодаттю Божою. Хочеш отримати молитву, працюй в молитві. Бог, який бачить, як ти пильно шукаєш молитви, сам дасть молитву" [25, с. 49-50]. Природа релігійного трансперсонального досвіду така, що він засвідчує і верифрікує сам себе. Тут ми погоджуємося 3 В. Джеймсом, який підкреслював: "містичні стани, що досягли свого повного розвитку, є абсолютно авторитетними для осіб, що їх переживають" [6, с. 329]. Можна порівняти це з висловлюванням відомого православного аскета-подвижника Сілуана Афонського, котрий зазначає: "Коли Бог являє себе у великому світлі, тоді неможливий жоден сумнів, що це Господь, Творець і Вседержитель" [18, с. 18].

А ось інший приклад художнього натхнення, яке також має усі ознаки релігійності і трансцендентності. Мемуари Донато Браманте, друга Рафраеля, свідчать про те, що блискучий художній образ Діви Марії, над яким майстер працював багато років, також бере свої витоки не з індивідуальної свідомості, а з надіндивідуальних і надприродних джерел: "Одного разу я йому [Рафаелю] 3 відкритим і повним серцем висловлював здивування чарівними образами Мадонни і Св. Сімейства і переконливо просив його, щоб він розгадав мені: де, в якому світі він бачив цю незрівнянну красу, зворушливий погляд і вираз неповторний в образі Пресвятої Діви <...> Рафраель розповів, що від самої ніжної юності завжди полум'яніло в душі його особливе святе почуття до Матері Божої <...> від самого першого спонукання до живопису він мав у собі непоборне бажання - живописати Діву Марію в небесній ії̈ досконалості; але ніколи не смів довіряти своїм силам. <..> Однак іноді ніби небесна іскра закрадалася в його душу, і образ в світлих обрисах був перед ним так, як хотілось би намалювати його; але це була одна летюча мить: він не міг утримувати мрії в душі своїй <...> Одного разу вночі, коли він уві сні молився Пресвятій Діві, що бувало з ним часто, раптом від сильного хвилювання піднісся від сну. У темряві ночі погляд Рафаеля притягнутий був світлим видінням на стіні проти самого його ліжка, він зазирнув у нього і побачив, ще незакінчений образ Мадонни, що висів на стіні, відзначався лагідним сяйвом і здавався досконалим і ніби живим образом. Він так виражав свою божественність, що градом покотилися сльози з очей здивованого Рафаеля. <..> Але дивовижніше за все, що Рафраель знайшов в ньому саме те, чого шукав все життя і про що мав темне і неясне передчуття. ...Вставши вранці, ніби знову переродився: видіння навіки врізалося в його душу і почуття, i ось чому вдалося йому малювати Матір Божу в тому образі, в якому він носив Її в душі своїй" [27, с. 62].

Список видатних осіб, що пережили релігійне натхнення, можна було б продовжувати, але тут постають інші важливі питання: до якої міри трансперсональний стан свідомості можна викликати штучно; де завершуються можливості людської волі і в гру вступають сили надлюдські, в онтологічному характері яких не доводиться сумніватися? Усвідомлення людської немочі і конечності, неавтономності $€$ головною передумовою релігійного досвіду. Отже, по-перше, не все залежить виключно від активних зусиль людини, її знань і практики відповідних методів і прийомів індукції досвіду. В цьому плані досвід має здебільшого пасивний характер, коли на особу буквально "сходить" (без попередження) стан екстаза-шаленства, стан "благодаті" і вона погружається в нього без власної волі. По-друге, у цій пасивності досвіду переживається онтологічний (тобто реальний, буттєвий) характер тієї трансцендентної сили, яка його спричиняє. По-третє, тільки у надприродному стані благодаті людина здатна втілювати на практиці теологічні чесноти віри, надії і любові.

Символ як епіфанія. Людська особистість має унікальну можливість пізнати істину буття, вищі універсальні смисли буттєво, через символічну співпричетність, через внутрішній досвід переживання, а не логікодискурсивно. Американський православний богослов прот. Олександр (Шмеман) трактує символ як зв'язок зі священним, що уподібнює людину до Бога і водночас наближає її до власної сутності. В своїй фундаментальній роботі "Євхаристія. Таїнство Царства" Шмеман стверджує, що католицька схоластика редукувала значення поняття "символ", звівши його до знаку, алегорії, зображення - всього того, що відмінно від реальності і що протилежно реальності. Тож постає ключове запитання: чи відповідає таке редуковане (по суті матеріалістичне) католицьке розуміння символу як зображення давньому і первинному значенню цього слова? "Історія релігії показує, що чим давніший, глибший, органічніший символ, тим менше в ньому такої зовнішньої "зображувальності". І це так, тому що первинна функція символу не в тому, щоб зображувати (що передбачає відсутність зображуваного), а в тому, щоб являти і долучати (робити причетним) до явленого. Про символ можна сказати, що він не стільки схожий на реальність, що символізується, скільки причетний до неї, і тому може реально до неї долучати. Таким чином, різниця - радикальна - між теперішнім і первинним розумінням символу полягає в тому, що тепер символ є зображенням або знаком чогось іншого, чого при цьому в самому знакові реально немає (як немає реального, справжнього індіанця в акторі, що зображує його, або реальної води в хімічному її символі), тоді як в первинному розумінні символу він сам є явищем і присутністю Іншого, але саме як Іншого, тобто як реальності, котра в даних умовах і не може бути явленою інакше, аніж в символі" [33, с. 46].

Саме слово "символ" походить від грецького дієслова "поєдную", "тримаю разом". Тому в ньому, як слушно зазначає Шмеман, на відміну від знаку чи зображення, дві реальності - емпірична (видима) і метафрізична (невидима), поєднані не логічно ("А" означає "В"), не аналогічно ("А" зображує "В") і не причинно-наслідково ("А" $€$ причиною "В"), а епіфанічно ("А" являє "В"). "Одна реальність являє іншу... тільки тією мірою, якою сам символ причетний духовній реальності і здатний втілити їі. Іншими словами, в символі все являє духовну реальність, і в ньому все необхідно для ії явлення, але не вся духовна реальність являється і втілюється в символі. Символ завжди частковий, адже <..> по самій сутності своїй поєднує реальності неспівмірні, одна 3 яких залишається щодо іншої - абсолютно іншою. Хоч яким реальним був би символ, хай скільки долучав би нас до духовної реальності, функція його не в тому, щоб "вгамувати" нашу спрагу, а в тому, щоб посилити іï" [33, с. 47-48]. Символізм християнського релігійного досвіду найповніше виражається в церковних таїнствах, і найголовніше в Євхаристії, коли під час звершення літургії хліб і вино поєднуються 3 Божеством Христа і перетворюються на його Плоть і Кров. Хліб і вино - це 
символи, які виражають невимовну божественну реальність, вміщають те, що не можна вмістити, приближають розуміння того, що лежить за межами розуміння, долучають і наближають особу до особливого духовного стану ("Царства Небесного"), даруючи їй благодатні дари Святого Духу: смирення і сумірність, бачення власних гріхів і каяття, милосердя і співчуття. Якщо "Бог це любов" (формула євангеліста Іоанна Богослова), то. відповідно, і Царство Небесне $є$ царством любові, в яке не можна фрізично потрапити, але до якого можна бути містичним чином причетним у таїнстві Євхаристії. Недарма серед вимог до причасників найголовнішою $€$ моральна вимога прощення і примирення з ближнім, тому що без моральної чистоти того, хто бере участь у таїнстві, останнє не буде вважатися дійсним.

Поворот свідомості: від нігілістичної доби до ностальгії за священним. Епоха модерну характеризується нігілістичним твердженням "смерті бога". Відмова від Абсолюту може породити лише культ "квазіабсолютів" (М. Шелер): партії, нації, раси, держави, прав людини. Водночас нігілістичне переконання, яке заволоділо масами, очевидно, не могло бути теоретичною конструкцією окремо взятих кабінетних вчених на кшталт Фрідріха Ніцше чи Карла Маркса. Ясно, що теза "бог помер" виражала і відображала внутрішній досвід багатьох людей, їх внутрішню впевненість у такій картині світу, де Бог є ілюзією. Відповідно, жодна теоретична, раціональна фрілософська конструкція не зможе подолати нігілістичну установку. Тільки зворотний, позитивний досвід присутності божественного $€$ ефективними ліками проти цієї духовної сліпоти. У статті "Навіщо поети?" М. Гайдеґґер зазначає, що саме поети покликані здійснити поворот сучасної свідомості - від нігілістичної картини світу, раціоналістично-дискурсивного уявлення та обчислення до сердечної глибини, де суще пізнається в своїй істині через споглядання. Поети суть "глашатаї священного". Це ті з смертних, хто в останні темні часи, коли бог помер, а священне приховалося, шукають сліди священного. "Під час ночі світу поет розповідає про священне, а сама ніч світу $є$ священна ніч... Благо дає натяк, закликаючи священне. Священне зв'язує з божественним. Божественне зближує з Богом. Поети несуть смертним слід богів, що втекли в мороці ночі світу" [31, с. 29].

Отже, за Гайдеґґером, порятунок від темної безбожної доби калі-юги слід шукати у поетичній творчості. Шукаючи сліди божественного, вслуховуючись у знаки і символи, які дає нам буття, ми повинні приготувати в нашому серці місце для здійснення головної історичної "Події" ("Ereignis", рос. "со-бытия") - явлення священного буття в своїй істинності. Коротко пояснимо, який сенс Гайдеґер вкладає в поняття "історія" та "Подія". Передусім слід зазначити, що, на думку фрілософра, всесвітня історія є історією Європи, а ще точніше, історією європейської філософрії. Але останню Гайдеґґер розуміє під специфічним кутом зору, а саме як "онтоісторію", тобто історію буття. Онтоісторія - це історія розгортання логосу та його розкриття (висвітлення) в історії фрілософіії від досократиків до Ніцше. Траєкторія цієї онтоісторії рухається такими віхами: від розуміння буття як "алетеї" (відкритості), тобто істини буття як не-сущого (для мислителя синонімом "істини буття" $є$ сфрера священного), до всіх можливих метафрізичних підмін цієї істини буття на "буття сущого", "природу", "ідею", "сутність" i, нарешті, "суб'єкт" і "волю". Онтоісторія, на думку Гайдеґґера, завдяки цій підміні і забуттю "істини буття", приречена на своє завершення в нігілізмі.

Гайдеґґер також говорить про есхатологію онтоісторії, про знання, яке "істина буття" дає людям про себе в останні часи. Люди забувають про буття, і воно залишає людей. Водночас, покидаючи світ та фрілософський дискурс, буття самим фрактом свого зникнення, через нігілізм, через царство штучності, волі до влади, техніки, відчуження, подає людям знак - знак про те, що людям чогось не вистачає, знак нестачі чогось фундаментального, без чого ми втрачаємо власну сутність. Отже, сьогоднішній світ може врятувати ностальгія за священним. Проф. Фрідріх-Вільгельм фон Херрманн, колишній секретар Мартіна Гайдеґґера, зазначає з цього приводу: "Гайдеґґер сам говорив про "втечу богів" та їх можливе повернення. Він виходив з того, що буття залишило світ невипадково і що його віддалення також було частиною онтоісторичної долі, тобто посилом, пов'язаним 3 невірним тлумаченням буття як буття загалом (тобто розумінням буття як сутності сущого, природи речей, ідеї і т. д. - Прим. наші), щоб дати негативним чином знати про можливість вірного тлумачення про істину буття як Подію. Але разом із залишенням людей з боку буття відбувалося залишення людей Богом. Суще втратило Бога. У Гайдеґґера було два джерела його думки про покинутість сущого Богом. Перше - це Гельдерлін, а друге - Ніцше. Гельдерлін оплакував відхід богів і ангелів з життя людей і передбачував їхнє повернення - повернення божественного і богів" [32, с. 95]. Вслід за видатним поетом Гайдеґер очікував на великий поворот світової історії. Мислитель міркує над Dasein як відкритістю - буттям людини в її автентичному модусі, яка повинна стати місцем виявлення істини буття, місцем його присутності. Подія (Ereignis) ним визначається як прихід, місце явлення "останнього Бога", якого ще не було, який буде в майбутньому і виявить себе з глибини людини. Це внутрішній Бог, який народиться з туги за втраченими старими богами. Не людина чекає Бога, який прийде, а Бог чекає на людину: чекає, поки вона стане автентичним Da ("ось") - місцем, в якому Бог зможе з'явитися, відкритися, збутися. Іншими словами, "останній Бог" являє власну божественність не по той бік буття, а зсередини людського буття, яке буде правильним чином налаштоване.

Підсумовуючи Гайдеґґера в християнському ключі, зазначимо, що реванш сакрального описується своєрідним герменевтичним колом. 3 одного боку, від свобідного вибору людини залежить, чи "впустить" вона Бога у свій "світ" або "закриється" від нього у звичній темряві невігластва. 3 іншого боку, шукати священне, прагнути до невимовної істини буття спонукає (кличе) сама істина буття, покликання божественної благодаті. "Без Волі Отця ніхто до Мене не приходить", а значить, віра як налаштованість на безкінечне $\epsilon$, в кінцевому рахунку, даром Святого Духа, який дається як відповідь на правильно поставлені внутрішні питання.

Висновки. У сьогоднішніх постмодерних реаліях людина характеризується браком духовної складової, замкненістю та ізольованістю в своєму індивідуальному існуванні, в якому утверджується вищість матеріальних цінностей та ігноруються речі трансцендентного порядку. Відповідно, симптомами бездуховності виступають негативні явища самотності, екзистенційного вакууму, депресії, суїцидальних настроїв, нестримного гедонізму тощо. Виходом з екзистенційної кризи, на думку авторів статті, $€$ "поворот свідомості", екзистенційна налаштованість особистості на священну таємницю буття як вищу духовну інстанцію, яка здатна наповнити існування людини смислом, значущістю і щастям. Автентичне буття особистості передбачає розімкненість, орієнтацію на царину вічних "верховних цінностей". У статті зазначається, що вищим проявом духовності $€$ трансперсональний досвід, що є конститутивним в процесі олюд- 
нення, наближення людини до власної сутності. Трансперсональний досвід, в якому людина переживає присутність божественної реальності як безумовної любові і джерела всіх благ, - це те, що відкриває особистості шлях до бачення інших в світлі цієї любові як унікальних і неповторних Ти. Через любов-милосердя індивід уподібнюється до Бога, а в його біологічній природі проступає духовна, іпостасна (особистісна) складова. Серед особливостей трансперсонального досвіду вказується його амбівалентний активно-пасивний характер, де трансценденція, тобто переростання власних меж індивідуальної свідомості, ніколи не є чистою самотрансценденцією. Підкреслюється, що реальність абсолютного, що відкривається в досвіді, осягається не раціонально-дискурсивно, а інтуїтивно-споглядально, через буттєву співпричетність. У релігійному натхненні відбувається відкриття особою невимовної таємниці божественного та багатства її смислів, якісна ініціатична трансформація через символічну смерть і воскресіння.

Яскравим прикладом такої особистісної трансформації в античному світі є знамениті Елевсинські містерії, а в християнську добу - церковні таїнства, і особливо центральне таїнство Євхаристії (причастя). Дохристиянські і християнські містерії-таїнства дають людині надію на воскресіння, безсмертя та вічне блаженство у вічному житті. Зауважується, що символізм таїнств несе не зображувальний, а епіфанічний характер, де духовна реальність розкривається і проявляється у матеріальних знаках, поєднуючи внутрішньосвітове і несвітове. На прикладі вчення Гайдеґґера утверджується, що коріння модерного розчаклування світу, нігілізму і забуття священної істини буття слід шукати в самій його історії, тобто в об'єктивній онтоісторії. Водночас від волі людини залежить, чи захоче вона відмовитись від своєї нігілістичної і цинічної утилітарно-прагматичної установки світосприйняття і змінити модус буття на безкорисне "посутнісне" ставлення до дійсності. Ностальгія за повнотою буття, за цілісною картиною світу і бездушний технократичний і об'єктний характер сучасної цивілізації, в якій панує відчуження та безособовість, повинні стати поворотним моментом на шляху до головної події онтоісторії - реваншу сакрального і повернення "останнього бога" (М. Гайдеґґер).

\section{СПИСОК ВИКОРИСТАНИХ ДЖЕРЕЛ}

1. Вітгенштайн Л. Tractatus Logico-Philosophicus; Філософські дослідження / Л. Вітгенштайн; Пер. з нім. Є. Поповича. - К.: Основи, 1995. $311 \mathrm{c}$.

2. Витгенштейн Л. Голубая и коричневая книги. Предварительные материалы к "Философским исследованиям" / Л. Витгенштейн; Пер. с англ. В. А. Суровцева, В. В. Иткина. - Новосибирск: Сиб. унив. изд-во, 2008. - $256 \mathrm{c}$.

3. Гегель Г. Избранные афоризмы [Електронний ресурс] / Г. Гегель // Гегель Г. Введение в историю философии. Лекции по эстетике. Наука логики. Философия природы. - Режим доступу: логики. Философия природы. - Режим доступу:
https://books.google.com.ua/books?id=t21_DwAAQBAJ\&printsec=frontcove $\mathrm{r} \& \mathrm{hl}=\mathrm{ru} \# \mathrm{v}=$ onepage $\& \mathrm{q} \& \mathrm{f}=$ false

4. Генон Г. Заметки об инициации / Р. Генон; Пер. с фр. Т. М. Фадеевой, Ю. Н. Стесранова // Генон Р. Символика креста. - М.: Прогресс-Традиция, 2004. - С. 355-693. $290 \mathrm{c}$.

5. Делез Ж. Логика смысла / Ж. Делез. - М.: Изд-во МГУ, 1998. -

6. Джеймс У. Многообразие религиозного опыта / У. Джеймс; Пер. с англ. под общ. ред. П. С. Гуревича, С. Я. Левит. - М.: Наука, 1993. $432 \mathrm{c}$.

7. Диоген Лаэртский. О жизни, учениях и изречениях знаменитых философов / Диоген Лаэртский; Пер. с древнегреч. М. Л. Гаспарова. М.: Мысль, 1986. -571 с

8. Луцій Апулей. Метаморфози, або Золотий осел / Луцій Апулей; Пер. з лат. Й. Кобів, Ю. Цимбалюк. - К.: Дніпро, 1982. - 439 с.

9. Малявин В. Комментарии к "Дао-Дэ цзин" / В. Малявин // Лао-цзы. Дао-Дэ цзин. Книга о Пути жизни; Комментарии, составление и перевод В. В. Малявина. - М.: Феория, 2006. - 704 с.

10. Мей Р. Смысл тревоги / Р. Мей; Пер. с англ. М. И. Завелова, А. Ю. Сибуриной. - М.: Класс, 2001. -410 с.

11. Минин П. Мистицизм и его природа / П. Минин. - К.: Пролог, 2003. $-146 \mathrm{c}$.
12. Мусин М. 3. Неистовый у врат поэзии / М. 3. Мусин // Соловьевские исследования. - Вып. 3 (47), ИГЭУ, 2015. - С. 67-80.

13. Отто В. Греческие боги. Картина божественного в зеркале греческого духа. / В. Отто; Пер. с нем. О. С. Ракитнянской. - СПб.: Владимир Даль, 2019. - 320 с.

14. Пащенко В. І., Пащенко Н. І. Антична література: підручник для студентів вищих навчальних закладів / В. І. Пащенко, Н. І. Пащенко. К.: Либідь, 2001. -720 с.

15. Пиндар. Хоровая лирика / Пиндар; Пер. с древнегр. М. Е. ГрабарьПассек // Хрестоматия по античной литературе. В 2-х тт. Для высших учебных заведений; Под ред. Н. Ф. Дератани, Н. А. Тимофеевой. Т. 1. Греческая литература. - М.: Просвещение, 1965. - С. 111-121.

16. Платон. Діалоги / Платон; Пер. 3 давньогр. - Харків: Фоліо, 2008. - $349 \mathrm{c}$.

17. Сахаров (Софроний). Видеть Бога как Он есть. / архим. Софроний Сахаров; Изд. 3-е, испр. - Свято-Иоанно-Предтеченский монастырь, Свято-Троицкая Сергиева Лавра, 2006. - 400 с.

18. Силуан Афонский. Жизнь и поучения / Силуан Афонский. Минск: Паломникъ, 1991. - 464 с

19. Сокулер 3. Людвиг Витгенштейн и его место в философии $\mathrm{XX}$ века [Електронний ресурс] / 3. Сокулер. - Режим доступу: http://www.bim-bad.ru/docs/sokuler_vittgenstein.pdf

20. Софокл. Драмы / Софокл; Пер. с древнегреч. Ф. Ф. Зелинского, О. В. Смыки и В. Н. Ярхо под ред. М. Л. Гаспарова и В. Н. Ярхо. - М.: Наука, 1990. - 606 с.

21. Тейлор Ч. Секулярна доба. Книга перша / Ч. Тейлор; Пер. 3 англ. О. Панича. Вид. 2-ге. - К.: Дух і Літера, 2018. - 664 с.

22. Тиллих П. Мужество быть / П. Тиллих; Пер. с англ.

Т. И. Вевюрко. // П. Тиллих. Избранное. - М.: Юрист, 1995. - С. 7-131.

23. Торчинов Е. Религии мира. Опыт запредельного / Е. Торчинов. - СПб.: Академическая книга, 2000. - 428 с.

24. Уилбер К. Око духа. Интегральное видение для слегка свихнувшегося мира / К. Уилбер. - М.: Золотая амфора, 2008. - 536 с.

25. Умное делание. О молитве Иисусовой. Сборник поучений Святых Отцов и опытных ея деятелей. - Изд-во Валаамского монастыря. 1936. -384 c.

26. Фидлер Д. Иисус Христос - Солнце Бога. Античная космология и раннехристианский символизм / Д. Фидлер; Пер.с англ. А. Архиповой. - М.: Издательский дом София, 2005. - 432 с.

27. Флоренский П. Иконостас / П. Флоренский. - СПб.: Мифрил, Русская книга, 1993. - 365 с.

28. Фрагменты ранних греческих философов. От эпических теокосмогоний до возникновения атомистики. Ч. 1. - М.: Наука, 1989. $576 \mathrm{c}$.

29. Франкл В. Человек в поисках смысла / В. Франкл; Пер. с англ. и нем. Д. А. Леонтьева, М. П. Папуша, Е. В. Эйдмана. - М.: Республика, 1990. - 368 c.

30. Хайдеггер М. Вещь / М. Хайдеггер; Пер. с нем. В. В. Бибихина // М. Хайдеггер. Время и бытие. Статьи и выступления. - М.: Республика, 1993. - С. 316-326.

31. Хайдеггер М. К чему поэты? [Електронний ресурс] / М. Хайдегrер; Пер. с нем. В. Бакусева. - Режим доступу: http://www.proza.ru/ 2012/02/23/632

32. Херрманн Ф. Понятие феноменологии у Хайдеггера и Гуссерля / Ф. Херрманн; Пер. с нем. И. Инишева. - Мн.: Пропилеи, 2001. - 192 с.

33. Шмеман А., прот. Евхаристия. Таинство Царства / прот. Александр Шмеман. - М.: Гранат, 2006. - 326 с.

34. Элиаде М. История веры и религиозных идей. Т. 1. От каменного века до Элевсинских мистерий / М. Элиаде; Пер. с фр., 2-е изд. - М.: Критерион, 2002. - 450 с.

\section{REFERENCES}

1. Wittgenstein, L. (1995). Tractatus Logico-Philosophicus; Philosophical Investigations. Kyiv, Osnovy (In Ukrainian.)

2. Wittgenstein, L. (2008). Blue and Brown Books. Novosibirsk, Sib. univ. izd-vo. (In Russian).

3. Hegel, G. Aphorisms from the wastebook. Retrieved from https://books.google.com.ua/books?id=t21_DwAAQBAJ\&printsec=frontcove

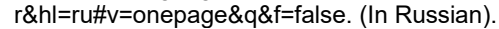

4. Guénon, R. (2004). Perspectives on Initiation. In: Guénon R. The Symbolism of the Cross. Moscow, Progress-Tradicija (In Russian).

5. Deleuze, G. (1998). The Logic of Sense. Moscow, Izd-vo MGU (In Russian)

6. James, W. (1993). The Varieties of Religious Experience. Moscow, Nauka (In Russian).

7. Diogenes Laërtius. (1986). Lives and Opinions of Eminent Philosophers. Moscow, Mysl' (In Russian).

8. Lucius Apuleius. (1982). Metamorphoses or The Golden Ass. Kyiv, Dnipro (In Ukrainian).

9. Maljavin, V. (2006). Kommentarii k "Daodjeczin" [Comments to TaoTeChing]. In Laozi. TaoTeChing. Moscow, Feorija.

10. May, R. (2001). The Meaning of Anxiety. Moscow, Klass (In Russian).

11. Minin, P. (2003). Misticizm i ego priroda [Mysticism and its essence]. Kyiv, Prolog.

12. Musin, M. Z. (2015). Neistovyj u vrat pojezii [Furious at the gates of poetry]. In: Solov'evskie issleddovanija [Solovyev investigations]. Vol. 3 (47). IGJeU, 67-80.

13. Otto, W. (2019). The Homeric Gods. Sankt-Petersburg, Vladimir Dal' (In Russian). 
14. Pashhenko V.I., Pashhenko N.I. (2001). Antychna literatura: pidruchnyk dlja studentiv vyshhyh navchal'nyh zakladiv [Antique literature: a textbook for university students]. Kyiv, Lybid'.

15. Pindar. (1965). Paeans. In: Hrestomatija po antichnoj literature. $V$ 2-h t. T. 1. Grecheskaja literature [Anthology on Antique literature. In 2 volumes. For universities]. Moscow, Prosveshhenie, 111-121.

16. Plato. (2008). Dialogy [Dialogues]. Harkiv, Folio. (In Ukrainian).

17. Saharov (Sofronij). (2006). Videt' Boga kak On est' [To see the God how He is]. Svjato-loanno-Predtechenskij monastyr', Svjato-Troickaja Sergieva Lavra.

18. Silouan the Athonite. (1991). The Life and Teachings. Minsk, Palomnik (In Russian).

19. Sokuler, Z. Ljudvig Vitgenshtejn $i$ ego mesto $v$ filosofii $X X$ veka [Ludwig Wittgenstein and his place in philosophy of the $20^{\text {th }}$ century]. Retrieved from http://www.bim-bad.ru/docs/sokuler_vittgenstein.pdf

20. Sophocles. (1990). Dramas. Moscow, Nauka (In Russian)

21. Taylor, Ch. (2018). A Secular Age. Kyiv, Duh i Litera.

22. Tillich, P. (1995). The Courage to Be. In: Tillich, P. Izbrannoe [Collected writings]. Moscow, Jurist, 7-131 (In Russian).

23. Torchinov, E. (2000). Religii mira. Opyt zapredel'nogo [Religions of the World. The experience of Transcendent]. Sankt-Petersburg, Akademicheskaja kniga.

24. Wilber, K. (2008). The Integral Vision. Moscow, Zolotaja amfora (In Russian)

25. Umnoe delanie O molitve lisusovoj. Sbornik pouchenij Svjatyh Otcov i opytnyh eja dejatelej. [Clever doing. On the Jesus Prayer. Collection of the Holy Fathers teachings and their experience actions]. (1936). Izd-vo Valaamskogo monastyria.

26. Fideler, D. (2005). Jesus Christ, Sun of God. Ancient Cosmology and Early Christian Symbolism. Moscow, Izdatel'skij dom Sofija (In Russian).

27. Florensky, P. (1993). Iconostasis. Sankt-Petersburg, Mifril, Russkaja kniga (In Russian).

28. Fragmenty rannih grecheskih filosofov. Ot jepicheskih teokosmogonij do vozniknovenija atomistiki. [Fragments by Early Greek Philosophers. From epic theocosmogonies to the origins of atomistics]. (1989). Vol. 1. Moscow, Nauka

29. Frankl, V. (1990). Man's Search for Meaning. Moscow, Respublika (In Russian).

30. Heidegger, M. (1993). Die Sache. In: Heidegger, M. Vremja i bytie. Stat'i i vystuplenija [Zeit und Sein. Artikel und Reden]. Moscow, Respublika, 316-326 (In Russian).

31. Heidegger, M. What Are Poets For? Retrieved from http: //www.proza.ru/2012/02/23/632. (In Russian).

32. Herrmann, F. (2001). Der Begriff der Phänomenologie bei Heidegger und Husserl. Minsk, Propilei (In Russian).

33. Shmeman, A. (2006). Evharistija. Tainstvo Carstva [Eucharist. Sacrament of the Kingdom]. Moscow, Granat.

34. Eliade, M. (2002). A History of Religious Ideas. Vol. 1: From the Stone Age to the Eleusinian Mysteries. Moscow, Kriterion (In Russian)

Надійшла до редколегії 07.10.21

A. Y. Morozov, Doctor of Philosophical Sciences, Associate Professor, Kyiv National University of Trade and Economics 19, Kyoto Street, Kyiv, 02156, Ukraine,

M. M. Rohozha, Doctor of Philosophical Sciences, Professor

Taras Shevchenko National University of Kyiv,

60, Volodymyrska Street, Kyiv, 01033, Ukraine

\section{TRANSPERSONAL EXPERIENCE AS A RESPONSE TO THE CHALLENGES OF NIHILISM: THE EUROPEAN CONTEXT}

The authors of the article focus their attention on the question of spirituality as an existential attitude of a person to the sacred mystery of being. The ambivalence of the realm of the sacred is that being transcendental at the same time in the act of Epiphany it manifests itself in a variety of symbolic forms of personal experience. It is argued that spirituality par excellence is transpersonal experience, which communicates the personality with the secret of the sacred as incomprehensible, not intellectually, but through existential involvement. In this intuitive experience of spiritual inspiration, the inexpressible truth of things beyond "facts" and "texts" is revealed to man. Transpersonal experience is constitutive in the process of a person's formation, his humanization. The transcendence of the individual takes place in it, which presupposes a constant movement of self improvement and self-overcoming, expansion of consciousness. This can be called spiritual initiation through a gradual moral transformation of the personality through symbolic death and resurrection, the purpose of which is the realization of existential fullness and the achievement of happiness-bliss. Historical forms of spiritual initiation are analyzed, such as the ancient mysteries and the Christian sacrament of the Eucharist. Particular attention is paid to the analysis of the Platonic understanding of inspiration-madness. It is noted that in the depths of modern secular culture, which is a consequence of the nihilistic attitude towards "disenchanting the world" and moral relativism, nostalgia for the sacred is inevitably born. Heidegger's teaching states that the roots of modern world disengagement, nihilism, and the oblivion of the sacred truth of being should be sought in the very history of being, that is, in objective "ontohistory". At the same time, it depends on the will of man whether he wants to abandon his nihilistic and cynical utilitarian-pragmatic attitude of worldview, and change the mode of existence to a useless "essential" attitude to reality. Nostalgia for the fullness of life, for a holistic picture of the world, on one hand, and the soulless technocratic and objective nature of modern civilization, dominated by alienation and impersonality, on another hand, should be a turning point on the way to the main event of ontohistory - the revenge of the sacred and the return of the "last god".

Key words: trans-personal experience, nihilism, relativism, moral relativism, truth of being, facts and things, silence, inspiration, spirituality, symbol, mysteries, nostalgia

А. Ю. Морозов, д-р филос. наук, доц.

Киевский национальный торгово-экономический университет,

ул. Киото, 19, г. Киев, 02156, Украина

М. М. Рогожа, д-р филос. наук, проф.

Киевский национальный университет имени Тараса Шевченко,

ул. Владимирская, 60, г. Киев, 01033, Украина

\section{ТРАНСПЕРСОНАЛЬНЫЙ ОПЫТ КАК ОТВЕТ НА ВЫЗОВЫ НИГИЛИЗМА: ЕВРОПЕЙСКИЙ КОНТЕКСТ}

Внимание сфокусировано на духовности как экзистенциальной настроенности человека на священную тайну бытия. Будучи трансцендентной, область священного в акте епифании проявляется в разнообразных символических формах личностного опьта. Утверждается, что духовностью par ехcellence выступает трансперсональный опыт, который сообщает личность с тайной священного как непостижимого не интеллектуально, а через бытийственную сопричастность. В этом интуитивном опыте духовного вдохновения человеку открывается неизреченная истина вещей по ту сторону "фактов" и "текстов". Трансперсональный опыт конститутивный в процессе становления человека, его очеловечивания. В нем происходит трансценденция индивидуального, что предполагает постоянное движение самосовершенствования и самопреодоления, расширения сознания. Это можно назвать духовной инициацией путём постепенного морального преображения личности через символическую смерть и воскресение, целью которой является реализация бытийной полноты и достижения счастья-блаженства. Анализируются исторические формы духовной инициации, такие как античные мистерии и христианское таинство Евхаристии. Особое внимание обращено к анализу платоновского понимания вдохновения-безумства. Отмечается, что в недрах современной секулярной культуры, которая является следствием нигилистической установки на "расколдовывание мира" и моральный релятивизм, неизбежно зарождается ностальгия по священному.

Ключевые слова: трансперсональный опыт, нигилизм, релятивизм, моральний релятивизм, истина бытия, факты и вещи, молчание, вдохновение, духовность, символ, мистерии, ностальгия. 